\title{
Experiences of Latino Participants Receiving Neutral Genomic Screening Results: A Qualitative Study
}

\author{
Amal W. Cheema ${ }^{a}$ Erica J. Sutton ${ }^{a}$ Annika T. Beck ${ }^{a}$ Idali Cuellar ${ }^{b}$ \\ Giovanna G. Moreno Garzon ${ }^{b}$ Valentina Hernandez ${ }^{c}$ Noralane M. Lindor ${ }^{d}$ \\ Gabriel Q. Shaibi ${ }^{e} \quad$ Iftikhar J. Kullo ${ }^{f}$ Richard R. Sharp ${ }^{a, g}$ \\ aBiomedical Ethics Research Program, Mayo Clinic, Rochester, MN, USA; ${ }^{\circ}$ Biospecimens Accessioning and \\ Processing, Mayo Clinic, Scottsdale, AZ, USA; 'Mountain Park Health Center, Phoenix, AZ, USA; dDepartment of \\ Health Sciences Research, Mayo Clinic, Scottsdale, AZ, USA; ${ }^{e}$ Center for Health Promotion and Disease Prevention, \\ Edson College of Nursing and Health Innovation, Arizona State University, Phoenix, AZ, USA; fDepartment of \\ Cardiovascular Medicine, Mayo Clinic, Rochester, MN, USA; ${ }^{9}$ Department of Health Sciences Research, Mayo Clinic, \\ Rochester, MN, USA
}

\section{Keywords}

Access to genetic services - Federally qualified health center · Genetic screening · Genetics research · Health disparities · Psychological and social impact

\begin{abstract}
Purpose: The aim of the study was to characterize experiences of Latino participants receiving genomic screening results. Methods: Participants were recruited at a federally qualified health center in the USA. In-person, semi-structured interviews were conducted in either Spanish or English by a bilingual, bicultural interviewer. Questions focused on motivations for pursuing genomic sequencing, concerns about receiving genomic screening results, and perceived benefits of receiving genomic information. Interviews were audio-recorded, transcribed, and translated. Results: Fifty individuals completed an interview; 39 were conducted in Spanish. Participants described mixed motivations for pursuing genomic screening. Participants viewed the benefits
\end{abstract}

of genomic screening in relation to not only their personal health but to the health of their families and their communities. Participants tended to have few concerns about genomic screening. Those concerns related to potential loss of privacy, misuses of genomic information, and the possibility of receiving distressing results. Some participants had misunderstandings about the scope of the test and the potential implications of their results. Most felt it was better to know about a genetic predisposition to disease than to remain uninformed. Participants felt that genomic screening was worthwhile. Discussion: This is one of the first studies to examine the experiences of Latino individuals receiving genomic screening results. Our results suggest that many Latino patients in the US see value in genomic screening and have limited concerns about its potential to cause harm. These results inform ongoing efforts to increase the availability of genomic medicine to underrepresented populations and add to our understanding of sociocultural drivers in the adoption of precision medicine.

(C) 2021 S. Karger AG, Basel

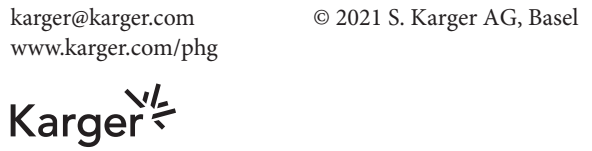




\section{Introduction}

Genomic medicine is expected to have a significant impact on health-care delivery and patient outcomes [1]. However, for genomic medicine to reach its full potential, several issues must be addressed [2,3]. In particular, issues of access and utilization in low-resource communities require attention [4-6]. It is unclear how underrepresented populations will respond to new forms of genomic screening, especially individuals who may be skeptical of health-care institutions, have low health literacy, or live in communities with limited access to new health-care technologies [7].

Federal investments in precision medicine and genomic research have stressed the importance of increased participation of underrepresented communities $[8,9]$. Prior studies have shown that members of racial and ethnic minorities are less likely to pursue medically recommended genetic testing and remain underrepresented in genomic research. Factors such as education and length of residency in the US [10], lack of insurance [11], lower socioeconomic status [12], and lower familiarity with genetics [13] all contribute to this disparity. These trends persist, despite high levels of interest in genomic medicine among racially diverse patients [14] and broad support for clinical trials across patient groups [15]. A combination of factors - including lack of familiarity with genomic screening, perceived difficulties obtaining follow-up medical care that might be recommended following a positive genomic test result, and mistrust of health-care institutions - may in part explain the challenge of expanding genomic medicine to include historically underrepresented individuals $[11,14,16,17]$.

Latinos are one of the largest demographic groups in the US $[18,19]$. This group - which includes Hispanic Americans whose heritage is from Spain, Mexico, Central America, South America, and the Spanish-speaking nations of the Caribbean - faces multiple barriers to obtaining health care, including issues of access, affordability, and language. Additionally, some Latino patients face deportation risks that may limit their access to health care [20]. As a result, Latinos may be less likely to participate in genomic research or clinical genetic testing in comparison to non-Hispanic whites [21-24].

Facilitators and barriers to Latino participation in genetic studies and use of genetic screening and testing remain understudied [25-27]. Similarly, studies describing the lived experiences of Latino patients who choose to receive genomic screening have been limited to date [23]. These studies are much needed since patient responses to genomic screening are directly related to their personal motivations for pursuing testing [28]. Understanding what motivates Latino patients, and patients from other underrepresented racial and ethnic minority communities, to pursue genetic testing can play a critical role in reducing the gap between those who are well positioned to benefit from precision medicine and those who are at risk of being excluded.

To inform ongoing efforts to increase the availability of genomic medicine to Latino patients, and improve our understanding of sociocultural factors influencing the adoption of new types of precision medicine, we sought to characterize the experiences of Latino patients who received genomic screening as part of a genomic implementation study [29]. In this article, we describe the motivations of Latino participants to pursue genomic sequencing, their concerns about genomic screening, and their overall assessment of the value of the experience.

\section{Methods}

\section{Recruitment}

Participants were recruited from a cohort of 500 self-identified Latino participants enrolled in the Return of Actionable Results Empirical (RAVE) study. The RAVE study is part of the National Human Genome Research Institute's Electronic Medical Records and Genomics (eMERGE) Network, which is assessing the impact of reporting genomic sequencing results to a diverse array of participants [30]. Participants were members of the Sangre Por Salud biobank at Mountain Park Health Center (MPHC), a federally qualified health center that provides care to patients in Phoenix, AZ, USA. Participants were required to be at least 18 years of age. Participants were not asked whether they were US citizens.

Study invitees were sent a study recruitment letter followed by a recruitment phone call from a research staff member. Individuals who expressed an interest in participating in the study were scheduled for an in-person education session with a study coordinator at MPHC. This session included an educational video that described genomic screening, the genes evaluated in the study, and the potential benefits and risks of participating. Although all costs associated with genetic testing were covered by the research study, participants were informed that they might receive information about their health that could require medical attention and that they would be responsible for those costs.

Following the educational session, interested participants provided their informed consent. The consent form described other risks of participating in research, such as the potential that health information might not be kept confidential. All participants who enrolled in the study agreed to receive genomic screening results and have those results placed into their electronic health record. Additional information about the study design is available elsewhere [29].

Samples were sequenced using the eMERGESeq panel of 68 medically actionable genes [31] as well as actionable single nucleo- 
tide variants in 13 additional genes [32]. Neutral genomic screening results (i.e., results that the research team felt did not require medical attention) were returned by mail with a follow-up telephone call to confirm receipt; medically actionable screening results were returned in person by a medical geneticist. A detailed description of the return of sequencing results from the study is available elsewhere [33]. Participants who received neutral results were invited to participate in an in-person, semi-structured interview to explore their experiences, including their motivations for pursuing genomic screening, their understanding of the results they received, their views regarding the potential benefits of genomic screening, and potential concerns they may have about genomic information. Results from those interviews are the focus of this study.

A majority of the individuals who were approached to participate in the genomic screening study were women, Spanish speakers, and had acceptable levels of literacy. To capture more diverse perspectives, we sought to oversample men, English-speaking participants, and individuals with lower levels of literacy. Interviewees were offered a USD 50 gift card for their time. The study was approved by the Mayo Clinic Institutional Review Board, and written informed consent was obtained from all participants.

\section{Data Collection}

The research team developed a semi-structured interview guide that encouraged participants to articulate their motivations for pursuing genomic screening in the context of a research study, express their views on genomic screening and results, describe any concerns they may have had in advance of sequencing, share their reactions to the results they received, relay their interpretation of the results, and share whether they found genomic sequencing worthwhile. The study team pilot tested the interview guide for flow and clarity with four volunteers, all of whom were members of a Community Advisory Board at MPHC. Three of these pilot interviews were conducted in Spanish and one in English. After each pilot interview, members of the study team discussed the interaction and adjusted the interview guide accordingly. For example, the question order was rearranged to improve flow, some questions were reworded or deleted, and new questions were added. The final interview guide was structured into sixsections examining study expectations and motivations for participating in the study and genomic screening, reactions to the results letter, interpretation of results, family sharing and reactions, description of perceived benefits or lifestyle changes stemming from the results, and final thoughts or questions.

This study was conducted at MPHC in Phoenix, AZ, USA. MPHC serves a population that is generally lower income, including many Latino patients and recent immigrants to the US. MPHC provides primary-care services to almost 90,000 patients annually.

Interviews were conducted in a private room to ensure patient confidentiality. A single bilingual and bicultural interviewer (IC) conducted interviews in either Spanish or English according to the participant's preference. All interviews were audio-recorded and the interviewer wrote field notes after each interview. A professional transcription service transcribed the English and Spanish interviews. Study team members fluent in the language of the interview then compared each transcript to the original audio and edited it for accuracy. After the Spanish language transcripts were reviewed, they were translated into English by a Spanish-English interpreter with certification from the National Board of Certifica- tion for Medical Interpreters. Data analysis was conducted using the English version of the transcripts, with crosschecking of Spanish versions.

\section{Data Analysis}

Transcripts from 13 interviews were used to develop an initial codebook using standard inductive analysis techniques [34]. This inductively generated codebook was then compared to a codebook used in a parallel study at Mayo Clinic. This parallel study involved 50 interviews with non-Hispanic white patients who received the same genomic screening test as participants in the study described here. Through iterative discussions with the research team, additional codes were added to facilitate comparative analyses across the two patient groups. The resulting codebook was then applied to additional interviews to assess the consistency of its application across coders. Final codes included family health history, motivations for pursuing genomic sequencing, understanding of genomic results, views about genetic testing and genetic technologies, sharing of results with family members, trust in health-care providers and organizations, expectations of participation or genomic screening, reactions to results, physician involvement and sharing of results with health-care providers, participant burden, and misunderstandings. Two qualitative research analysts in the Biomedical Ethics Program at Mayo Clinic independently coded all transcripts and discussed discrepancies until consensus was reached. Consensus codes were entered into QSR International's NVivo 11 Software (2015 release) for data management.

Thematic analysis was used to divide broader coding categories into more specific categories, which were subsequently analyzed to identify major results. Data memoing techniques were used to summarize major thematic areas. These memos were discussed by the study team and used to reach consensus on overarching themes.

\section{Results}

Seventy-two participants in the RAVE study who received genomic screening results that were not medically actionable were invited by telephone to participate in an interview. Eleven of these individuals declined the invitation. Sixty-one individuals agreed to participate and were scheduled for an in-person interview. Eleven of these individuals did not show up for their interview, yielding a total of 50 participants who completed an interview. Thirty-nine interviews were conducted in Spanish and 11 were conducted in English. Interviews ranged in length from 27 to $69 \mathrm{~min}$ with a mean length of $44 \mathrm{~min}$. Despite efforts to oversample men, more women participated in interviews than men. Men who were approached to participate often cited long work days and the demands of working several jobs as reasons for declining to participate. Our final cohort included 34 women and 16 men. Additional demographic information about participants is presented in Table 1 . 
Table 1. Demographic characteristics of participants

\begin{tabular}{|c|c|}
\hline Characteristic & $N(\%)$ \\
\hline \multicolumn{2}{|l|}{ Sex } \\
\hline Male & $16(32)$ \\
\hline Female & $34(68)$ \\
\hline \multicolumn{2}{|l|}{ Age, years at study invite } \\
\hline Mean (SD) & $48.0(12.1)$ \\
\hline Range & $20-73$ \\
\hline \multicolumn{2}{|l|}{ Language preferred for interview } \\
\hline Spanish & $39(78)$ \\
\hline English & $11(22)$ \\
\hline \multicolumn{2}{|l|}{ Phenotype } \\
\hline Hyperlipidemia & $48(96)$ \\
\hline Colon polyps & $1(2)$ \\
\hline Both & $1(2)$ \\
\hline \multicolumn{2}{|l|}{ Education } \\
\hline Grades 1-8 & $17(36)$ \\
\hline Grades 9-11 & $9(19)$ \\
\hline HS/GED & $9(19)$ \\
\hline College $1-3$ years & $7(14)$ \\
\hline College $4+$ years & $2(4)$ \\
\hline Graduate or professional school & $3(6)$ \\
\hline \multicolumn{2}{|c|}{ Self-reported assessment of discretionary income } \\
\hline More than enough & $9(21)$ \\
\hline Just enough & $15(36)$ \\
\hline Have to cut back & $9(21)$ \\
\hline Difficulty paying bills & $9(21)$ \\
\hline \multicolumn{2}{|l|}{ Insurance } \\
\hline Uninsured & $26(52)$ \\
\hline Insured (public and/or private) & $24(48)$ \\
\hline \multicolumn{2}{|c|}{ Have been unable, at any time, to access physician due to cos } \\
\hline Yes & $11(22)$ \\
\hline No & $39(78)$ \\
\hline \multicolumn{2}{|l|}{ Last checkup } \\
\hline Within past year & $29(64)$ \\
\hline Within past 2 years & $11(24)$ \\
\hline 5 or more years ago & $1(2)$ \\
\hline Not sure & $3(7)$ \\
\hline Never & $1(2)$ \\
\hline \multicolumn{2}{|l|}{ Health literacy } \\
\hline Inadequate & $11(22)$ \\
\hline Adequate & $39(78)$ \\
\hline
\end{tabular}

\section{Motivations for Pursuing Genomic Screening}

Participant motivations for pursuing genomic sequencing in the context of the RAVE study were mixed. While an interest in receiving personal health information was a common motivator for pursuing genomic sequencing, participants articulated this potential benefit in a variety of different ways. For example, many participants hoped genomic sequencing might help with preventative care: a belief well described by a 24 -year-old woman who said: "[Gene testing] is something I would like to know if it's something that could prevent future health problems" (P9, English speaking). Others cited responsibility to take care of their health as a reason to seek additional information that could inform their health behaviors:

\begin{abstract}
"Pues de alguna manera aprende uno a ser más responsable de su misma salud. Porque a veces como que hasta que no nos pasa algo o - entonces cuando se da uno cuenta que hay un estudio, es - es como empezar a ser más responsable de su misma salud ya, al participar y quizás prevenir, para saber si hay algo o si no hay nada también, para cuidarse más... O sea, tratar de ser más - tener una mejor educación respecto a - a la salud personal $y$ familiar. Porque a veces pudiéramos tener esa tendencia aa - a no - a no informarnos bien por no - por temor, por lo que pueda ser. No buscar esa ayuda que pudiera uno recibir."
\end{abstract}

"Well somehow one learns to be more responsible for our own health. Because sometimes until something happens to us or when you realize that there is a study, it is - is like starting to be more responsible for your own health already, by participating and perhaps preventing, to know if there is something or if there is nothing too, to take better care of yourself... That is, try to be more - have a better education with regard to - to personal health and family health. Because sometimes we can have a tendency to - to - to not - to - not inform ourselves correctly for not-out of fear, of what could be. Not look for the help that we could receive" (P25, male, 43 yo)

Although participants understood that they would receive genomic screening results, many noted a concurrent interest in receiving a broader type of clinical evaluation; participants often described the test results as a "health check" or as a type of "reassurance" regarding their health. A few participants also wanted to compare results from their genomic screening to their previous clinical evaluations: "To know - how my history is - from last year" (P16, female, 55 yo, Spanish-speaking). One participant "want[ed] to know about [his] diseases and also when [he was] going to die" (P18, male, 48 yo, Spanish-speaking).

Some participants described the clinical information provided by genomic screening in terms of "checking their genes" or as checking of the overall health of their blood:

"Pues para saber cómo estaba de salud... Más que nada eso, para saber cómo estaba yo de salud, de la sangre y todo eso."

"Well to know how my health was doing...More than anything it was that, to know how my health was, the blood and everything." (P7, female, 44 yo)

Others were interested in understanding what genetic risks they carried, sharing that they were unfamiliar with genetics and wanted to learn more about inheritance: 
"Pues en realidad, aprender un poco más acerca de cómo, uh, en los genes está, ah, toda esa información. De hecho aprendí bastante de cómo funcionan esas, uh, células o - no sé cómo llamarles....Esperaba pues saber qué traemos en los genes de mis antepasados, de mis abuelos, de mis padres, pero también quéle heredaba yo a mis hijos."

"Well in reality, learn more about how, uh, in the genes, there is, ah, all that information. Actually, I learned a lot about how all of that works, uh, cells or - I don't know what to call them....I was hoping to learn what we had in the genes of my ancestors, my grandparents, my parents, but also what I was passing down to my kids." (P40, male, 59 yo)

Along these lines, some participants indicated that they were motivated to have genomic screening because they hoped the results might provide insights into their family's medical history. This included "mak[ing] sure that [their family is] healthy" (P26, male, 28 yo, Englishspeaking) and preventing future disease in their families through a better understanding of their inherited genetic risk.

"[H] ace 10 años a mi papále dio leucemia crónica....no sabe uno si uno puede traer los genes también."

"[A]bout 10 years ago, my dad was diagnosed with chronic leukemia...one doesn't know if we might have those genes as well." (P34, female, 40 yo)

When asked what participants hoped to learn about themselves or their family through genomic sequencing, many participants identified specific illnesses that they hoped to learn more about, including diabetes, heart-related ailments, and cancers. Many participants had a personal connection to one or more of these diseases and mentioned a related family health history:

\footnotetext{
"Pues como tengo familia diabética...Tenemos ese problema, pues - pues yo quería saber sobre - ya ve que ahí dice de los genes."
}

"Well since I have family who is diabetic...we have that problem, well - well I wanted to know about - you know what it says about the genes." (P7, female, 44 yo)

In addition, participants often mentioned potential benefits to their families and the opportunity to contribute to a broader community or public good as among the motivating factors for pursuing genomic screening through the RAVE study. Beyond a desire to learn more about personal health, "helping others" was a common motivator. "[W]hy not contribute to something that could possibly help somebody else in the future?” (P39, female, 63 yo, English-speaking). Other participants saw themselves as "help[ing] the Hispanic and Chicanos" (P27, female, 67 yo, English-speaking).

Financial incentives were a motivator for a small number of participants. Specifically, the USD 50 gift card was mentioned by some as a significant motivator: "they was gonna give me the - the card thing, and I need it that day - at that time - very, very much" (P38, female, 64 yo, English-speaking). The convenience of genomic screening, combined with the fact that testing was free, contributed significantly to participant interest:

\begin{abstract}
"Y pos como uno - pos, uno en México qué va andar sabiendo de cosas de esas, ¿no? Si eso apenas aquí lo vengo aprendiendo. Porque en México, pos, no se usa na - bueno, quizá sí se use, va, pero muchas veces con la - como la gente no tenemos los medios para hacerlo, este, no nos lo hacemos ni lo practicamos. $Y$, pues, aquí se llegó la - la - la oportunidad de hacer, pues, dije, pos no voy a perder nada."

"And well since I - well, in Mexico we don't know about those
things, right? It is here that I am barely learning about this. Be-
cause in Mexico, well, this is not used - well, maybe it is, but
many times with the - well, we don't have the means to do this,
well, we don't do it or practice it. And, well, here is the - the-the
opportunity to do it, and I said, I have nothing to lose." (P5, fe-
male, 56 yo)
\end{abstract}

\section{Concerns about Genomic Screening}

For the majority of participants, the decision to pursue genomic sequencing was an easy choice. Few people recalled having any concerns before agreeing to participate. The concerns that were expressed included worries about privacy, financial implications, and the emotional burdens of genomic screening results.

A few interviewees questioned the protections in place to safeguard their privacy and expressed concerns about who might have access to their genomic information:

"I was iffy about having lab results out there that I didn't know what or where they were going to go...Yeah, I guess I was afraid that they could possibly be exposed or get into the wrong hands." (P39, female, 64 yo, Englishspeaking)

Others disclosed feelings of general distrust within their family or community toward research. One participant recounted a conversation she had had with her children, in which she tried to explain that her blood donation to a biobank "will help to, maybe, investigate how [researchers] can cure." She described her family's response to her participation as "mistrust, insecurity," as they asked if "[her] blood will be the guinea pig" (P29, female, 60 yo, Spanish-speaking). Due to financial barri-
Cheema et al. 
ers, some participants mentioned that they would not have access to technologies like genomic screening unless they were provided through health programs or research participation. As one participant said:

\begin{abstract}
"Pues yo pienso que está haciendo bastante al ayudarnos con esos - con esos programas y aún así sin cobrarnos. Porque hay veces que no - no contamos con el dinero suficiente - para hacer ese tipo de exámenes y son caros...Nosotros aprendemos. Que siempre he dicho, yo aprendí a perder el miedo aquí - de que si hay oportunidades tienes que aprovecharlas."
\end{abstract}

"I think that it is doing plenty by helping with those - those programs and still without charging us. Because there are times that we don't - don't have enough money - to do these types of studies that can be expensive.... We also learn. Like I have always said, I learned how to lose my fear here - if there are opportunities then you need to take advantage of them" (P34, female, 40 yo)

Similarly, another participant commented on the uniqueness of the opportunities made financially possible by clinical research:

"No tenía los medios y aquí me los iban a hacer, dije, ah, pos, qué bueno, va...Porque no en cualquier parte te andan haciendo estudios gratis....Entonces dije yo, bueno, pues hay que aprovechar porque no todo el tiempo."

"I did not have the means and here they were going to do them, I said, ah, well, that is good... Because not just any place will do these studies for free....So I said, good, well I need to take advantage because this does not happen all the time." (P5, female, 56 yo)

Other participants highlighted individual concerns related to their decision to pursue genomic screening, among them the potential psychosocial implications of learning that they have a medically actionable genetic variant. Before deciding to pursue genomic screening, they described having to reconcile a fear of discovering that they could have a medically actionable result with their belief that "it is better to know" and be able to take steps to prevent disease: "I said, 'Oh, what if they say I have something bad'. That was my concern, but it's better to know right now" (P19, female, 50 yo, Spanish-speaking). Other participants expressed concerns about the downstream effects of learning that they have a medically actionable result, such as paying for expensive medications to manage that risk:

"No, solamente nomás de que si está uno - porque luego está uno enfermo de algo y luego ya no lo quieren atender a uno porque están más caras las medicinas y todo eso, que ya no quieren ver- lo. Pero yo dije, de todas maneras si estoy enfermo de algo, de todos modos tengo que darme cuenta para saber, ¿verdad? Para cuidarse uno más o algo. Hacer un - un sacrificio uno de salir adelante con su enfermedad y eso."

"Just, if one is - because when one is sick they no longer want to treat you because medications are more expensive and all of that, they don't want to see you. But I said, even if I am ill, I still need to find out, right? To take better care of myself or something. To make $a-a$ sacrifice and getting ahead of a disease with all of that" (P8, male, 42 yo)

Despite these concerns, participants placed a high value on the health information they expected to receive and agreed to participate.

\section{Assessments of the Value of Genomic Screening}

Interviewees offered positive evaluations of their participation in the RAVE study and emphasized how valuable it was to participate in genetic studies they "didn't know [...] were available" to them (P44, female, 40 yo, Spanish-speaking). Mirroring their motivations for pursuing genomic screening, participants felt that their results would be useful to themselves, to their doctors, and to their families. Some participants also hoped that genomic screening might encourage their community to live more healthfully:

"Pues que le ayuden a - a la gente a comer bien, de cómo cuidarse, pues. Comer sano y hacer ejercicio, dormir bien y si tienen problemas o sienten algo, que vengan rápido para que les ayuden a - a buscar ayuda. No esperar a que se le haga más grande a uno, ¿verdad?"

"Well that they help - help people to eat better, to learn how to better care for themselves. Eat healthier and exercise, sleep better and if they have problems or feel something, to come quickly to get help or - or to seek help. To not wait until it becomes something bigger, right?" (P8, male, 42 yo)

Many participants connected the value of their participation to helping advance scientific knowledge within the Latino community specifically, hopeful that genetic studies like the RAVE study might identify unique health concerns in their community:

"Eh, que trate de - como de - de apoyarnos como decir, bueno, estos son los riesgos de la comunidad, hay que hacer esto y esto para no tener tanto riesgo de."

"Uh, that it will try to - like to - to support us by saying, well, these are the risks of the community, you have to do this and this to not have so much risk of that." (P6, female, 46 yo) 
Other interviewees expressed gratitude to researchers for establishing a community-focused initiative and for inviting them to participate. Some welcomed more opportunities to participate in research. When asked about additional advice or suggestions for the research team, several participants requested, " $t]$ hat more studies be done - by, reviewing other types of genes. It is a lot of help for the community" (P46, female, 65 yo, Spanish-speaking).

For some interviewees, the value of receiving genomic results was tied to feelings of "relief" (P43, female, 48 yo, English-speaking) and "peace of mind" (P2, female, 35 yo, Spanish-speaking) that accompanied receiving their neutral results:

"[¿Valió la pena participar en este estudio?] Cien por ciento. [Okay. ¿Cuál sería la razón principal?] Pues que-primeramente que me dio un- una satisfacción saber - satisfacción, ¿se dice, no? Saber pues que ha- ha- ha- hay, digamos, un - una mínima parte, eh, de mi salud pues está - está bien, ¿no? Porque si le hablara de generalmente pues, um, usted dice que hay miles de genes, entonces pues soy feliz con - con - con eso que-que supe, ¿no?"

"[Was it worthwhile to participate in this study?] One hundred percent. [Okay. What is the main reason for this?] Well - first of all because it gave me a - a satisfaction to know - satisfaction is how you say it, right? To know that there - there - there is, let's say, a - a minimal part of my health that is - is good, right? Because if I were to speak generally well, um, you said there are thousands ofgenes, so I am happy with - with - with what - what I know, right?" (P14, male, 63 yo)

In contrast, other interviewees' attributions of value revealed misunderstandings about the outcomes of the research or scope of the genomic results they received. For example, a participant assumed that cancer is caused by a single genetic anomaly: "Yes [participating in the study and receiving genomic results was worth it to me]. Because I know that I don't have the cancer gene" (P4, female, 40 yo, Spanish-speaking).

Most participants talked about their participation as worthwhile because they received genetic health information, whether or not they fully appreciated what that information meant for them or their families:

[W]as it worthwhile for you to participate in the study?] I think so, yeah. [Okay. And what would be a reason?] The reason being you checked my genes - and my genes are okay...Um, as far as my healthwise goes, you know, my - my cholesterol, you know, my, I don't - what do my genes say about my cholesterol, um, I didn't understand that part. (P31, female, 64 yo, English-Speaking)
Although some aspects of genomic screening, particularly the relationship between genomic results and other health information or its potential impact on future care, were not entirely clear to all participants, most were grateful for the opportunity and felt that it had been a good experience.

\section{Discussion}

The benefits of genomic medicine will be limited if barriers to engaging underrepresented populations are not adequately addressed. By understanding the motivations and concerns associated with genomic screening across diverse segments of the population, researchers will be better positioned to inform the implementation of individualized medicine across health-care settings. With this context, we sought to examine the experiences of Latino participants who received genomic screening in the context of a translational research study. As one of the first studies to characterize the experiences of Latino participants who received genomic screening, our study provides important insights into future efforts to expand genomic medicine to include more diverse communities and settings.

First, we found that while Latino participants often reported multiple sources of interest in genomic screening, a consistent and strong motivation across participants was a desire for greater information related to personal or family health risks. This interest tended to outweigh abstract concerns about genetic discrimination or potential psychosocial burdens that might be associated with managing genomic results. This finding is consistent with prior studies $[22,35,36]$ and suggests that a key determinant in response to new forms of genomic medicine will be the perceived value of genomic screening results.

Previous research with rural Mexican-Americans has shown that patients did not always connect increased risk of disease with genetic traits [36]. By contrast, we found that many of our participants readily saw connections between genes and health. For example, they shared personal health histories linking disease inheritance with genetics. Participants also noted an interest in receiving additional information about the connections between genetics and specific diseases such as cancer and diabetes [37]. Of particular interest were diseases that participants perceived as more common within their communities. A collectivist orientation is a key cultural construct in many Latino communities [38] and may play an important role in shaping opinions about the relevance of genomic screening programs to local community needs. 
Second, our results highlight a number of misunderstandings about genomic screening and its relevance to health and ongoing disease management. For example, some participants expected that genomic screening results would provide a comprehensive description of their overall health and clarify with certainty whether they will or will not develop specific diseases in the future. The expectation that genomic evaluation will provide accurate, highly detailed personal health predictions is a form of diagnostic misconception [39]. The potential for misunderstandings about the scope and accuracy of genomic screening highlights the importance of developing effective educational materials that adequately convey the limitations of genomic medicine. While it is difficult to prepare individuals for the many possible outcomes of genomic screening (e.g., positive, neutral, indeterminate results), this challenge is particularly important in populations with low health literacy. Our results suggest that Latino patients are indeed eager to learn about genomic medicine and how they might benefit from advances in genetics. In response to this enthusiasm, genomic research should strive to work more closely with community agencies in the design of educational materials describing not only the benefits of genomic screening but also its potential limitations and costs.

A third insight from our study is that while most Latino participants did not have significant concerns about genomic screening, many described worries about the emotional burdens associated with receiving a medically actionable result. These participants reported that they were initially hesitant to pursue genomic screening due to fears about receiving a result that might force them to make difficult life choices, such as how to pay for the costs of recommended medical care or whether to share their result with others in their family. Previous research has linked this hesitation with perceived burdens, noting that participants "may be forced to make unwanted or difficult lifestyle changes" in response to genetic knowledge [22]. Genomic screening initiatives in low-resource settings should proactively consider how to support patients who may receive a positive genomic screening result, including support related to the sharing of a positive test result with other family members and assistance in obtaining follow-up care at other clinical facilities that may provide specialized care related to genetic disorders. Additionally, it is critical to acknowledge the potential for downstream financial burdens associated with confirmatory diagnostic testing or clinical interventions that may reduce disease risks. Participants also commented on the fact that some med-

Latino Participants Receiving Neutral Genomic Screening Results ically actionable results might suggest a need to pursue costly clinical interventions to mitigate a disease risk. These findings underscore the importance of considering financial and other socioeconomic considerations that may impact receptivity to new forms of genomic medicine in low-resource settings.

Last, results from our study suggest that Latino participants in our sample believed that receiving genomic sequencing results, in the context of genomic research, was, on the whole, worthwhile. Participants felt that receiving neutral genomic screening results, even when those results did not directly inform their ongoing medical care, was helpful in giving them "peace of mind" and a sense of relief. Beyond any personal or familial health benefit, participants also appreciated the education about genomics that they received as part of the screening process and were glad to have learned more about these new medical tests. Many participants also hoped that their contribution to science would positively impact their community.

\section{Strengths and Limitations}

To the best of our knowledge, this study is the first to use qualitative methods to characterize Latino patient experiences receiving genomic screening results. Latinos have been underrepresented in studies examining the psychosocial implications of genetic testing to date. A strength of the study is that it enrolled individuals who had direct experience with genomic screening and had received personal results. Our sample size was large for a qualitative study and included men and women of a wide range of ages. Additionally, the qualitative methods we employed provided a rich description of the motivations and concerns of Latino participants, which situates their understandings of genomic screening within the context of other lived experiences that shape attitudes and beliefs about health care. The results we report can assist genomic researchers and others who are striving to increase the availability of genomic testing to Latino and other underrepresented populations that may not have convenient access to genetic counselors, advanced diagnostic testing, or medical specialists who can advise on the management of genetic risk factors.

Neutral genomic screening results from the RAVE study were reported to participants by mail and subsequently confirmed by phone, which provided an opportunity for patients to ask questions about their personal results. This telephone interaction with a study coordinator may have shaped participant understandings of their screening results, especially among individuals with low- 
er literacy or lower health literacy. Screening results were reported several months after participants initially enrolled in the study, which also may have influenced participants' recall of their motivations for pursuing genomic testing.

Another limitation of the study is that qualitative data analysis was done using English-versions of transcribed interviews, although a majority of interviews were conducted in Spanish. To mitigate this limitation, the study team took steps to preserve the meaning of Spanishspeaking participants' words throughout the translation process. First, a bilingual and bicultural interviewer translated all interviews, which presented several advantages, including: (1) the translator was familiar with the speakers' dialect and the context of the interviews, (2) a single translator ensured consistent translation of conceptually equivalent phrases and expressions across interviews [40], and (3) the translation and analysis process was designed so that the interpreter was an integral "part of the process of knowledge production" and participated in analyzing qualitative data and reaching consensus regarding major results [41].

Other limitations of the study include its reliance on data from a single clinic in Phoenix, AZ, USA. We acknowledge the heterogeneity of Latino communities in the US [42] and note that our findings may not be reflective of motivations or concerns found in Latino communities elsewhere. Participants were also compensated for the time required to complete the interview, which may have influenced their perceptions. Additionally, all participants in our study received neutral genomic screening results (i.e., results that were not viewed as requiring medical follow-up), and interviews were conducted after participants received those results. This sequence may have impacted participants' recall of their initial opinions about genomic screening and their decision to pursue genomic evaluation.

Future research should seek to better characterize potential misunderstandings of genomic screening that may exist in other communities. Those studies should include the perspectives of patients who receive care in diverse clinical settings. Additionally, our results highlight the need to characterize the array of financial and psychosocial burdens that Latino and other patients may encounter subsequent to receiving a clinically actionable genomic test result. Last, future research should explore why some patients elect to pursue genomic screening despite significant reservations about their ability to cope with the potential burdens of receiving a positive test result.

\section{Conclusion}

Our results provide much needed data on how Latino participants view the potential benefits and burdens of genomic screening. Our results suggest that Latino participants see value in genomic risk evaluation and have resolvable concerns about its potential to cause harm. These findings add to our understanding of sociocultural drivers in the adoption of precision medicine and can inform ongoing efforts to ensure equitable access to genomic medicine in Latino and other underrepresented communities.

\section{Acknowledgements}

The authors wish to thank the Mountain Park Health Center (Phoenix, AZ, USA) and members of Sangre Por Salud biobank as well as the interviewees who gave of their time to make this analysis possible. The authors also wish to thank the Sangre por Salud Community Advisory Board (CAB) members who participated in mock interviews, as well as the whole CAB for their input. Last, we would like to thank Dr. Davinder Singh for his support for the study and Crystal Ramos for her help with patient recruitment.

\section{Statement of Ethics}

The study was approved by the Mayo Clinic Institutional Review Board (IRB\#: 16-004342). All participants provided written informed consent to participate.

\section{Conflict of Interest Statement}

The authors have no conflicts of interest to disclose.

\section{Funding Sources}

This study was funded by the National Human Genome Research (grants U01HG04599 and U01HG006379) and the Mayo Clinic Center for Individualized Medicine.

\section{Author Contributions}

Study designed by: R.R.S., E.J.S., G.Q.S., N.L.L., A.T.B., I.C., G.M.G., and I.K. Interviews conducted by: I.C. Data analysis performed by: A.W.C., A.T.B., E.J.S., and I.C. Literature review conducted by: A.W.C. and A.T.B. Manuscript drafted by: A.W.C., E.J.S., and A.T.B. Manuscript edited by: all authors.
Cheema et al. 


\section{References}

1 Feero WG, Guttmacher AE, Collins FS. Genomic medicine: an updated primer. N Engl J Med. 2010;362(21):2001-11.

2 Joyner MJ, Paneth N. Seven questions for personalized medicine. JAMA. 2015;314(10): 999-1000.

3 Shendure J, Findlay GM, Snyder MW. Genomic medicine-progress, pitfalls, and promise. Cell. 2019;177(1):45-57.

4 Green ED, Guyer MS; National Human Genome Research Institute. Charting a course for genomic medicine from base pairs to bedside. Nature. 2011;470(7333):204.

5 Hindorff LA, Bonham VL, Brody LC, Ginoza MEC, Hutter CM, Manolio TA, et al. Prioritizing diversity in human genomics research Nat Rev Genet. 2018;19(3): 175.

6 Landry LG, Ali N, Williams DR, Rehm HL, Bonham VL. Lack of diversity in genomic databases is a barrier to translating precision medicine research into practice. Health Aff. 2018;37(5):780-5.

7 Funk C, Hefferon M, Kennedy B, Johnson C. Trust and Mistrust in Americans' Views of Scientific Experts. Pew Res Cent. 2019. https //www.pewresearch.org/science/2019/08/02/ trust-and-mistrust-in-americans-views-ofscientific-experts/.

8 Manolio TA, Chisholm RL, Ozenberger B, Roden DM, Williams MS, Wilson R, et al. Implementing genomic medicine in the clinic: the future is here. Genet Med. 2013;15(4):258.

9 Bentley AR, Callier S, Rotimi CN. Diversity and inclusion in genomic research: why the uneven progress?. J Community Genet. 2017; 8(4):255-66.

10 Pagán JA, Su D, Li L, Armstrong K, Asch DA. Racial and ethnic disparities in awareness of genetic testing for cancer risk. Am J Prev Med. 2009;37(6):524-30.

11 Suther S, Kiros GE. Barriers to the use of genetic testing: a study of racial and ethnic disparities. Genet Med. 2009;11(9):655.

12 Alford SH, McBride CM, Reid RJ, Larson EB, Baxevanis AD, Brody LC. Participation in genetic testing research varies by social group. Public Health Genomics. 2011;14(2):85-93.

13 Canedo JR, Miller ST, Myers HF, Sanderson M. Racial and ethnic differences in knowledge and attitudes about genetic testing in the US: systematic review. J Genet Couns. 2019;28(3):587-601.

14 Kaphingst KA, Stafford JD, McGowan LD, Seo J, Lachance CR, Goodman MS. Effects of racial and ethnic group and health literacy on responses to genomic risk information in a medically underserved population. Health Psychol. 2015;34(2):101.

15 Chen MS Jr, Lara PN, Dang JH, Paterniti DA, Kelly K. Twenty years post-NIH Revitalization Act: enhancing minority participation in clinical trials (EMPaCT): laying the groundwork for improving minority clinical trial accrual: renewing the case for enhancing minority participation in cancer clinical trials. Cancer. 2014;120(Suppl 7):1091-6.
16 Sheppard VB, Mays D, LaVeist T, Tercyak KP. Medical mistrust influences black women's level of engagement in BRCA $1 / 2$ genetic counseling and testing. J Natl Med Assoc. 2013;105(1):17-22.

17 Delikurt T, Williamson GR, Anastasiadou V, Skirton $\mathrm{H}$. A systematic review of factors that act as barriers to patient referral to genetic services. Eur J Hum Genet. 2015;23(6):739.

18 Velasco-Mondragon E, Jimenez A, PalladinoDavis AG, Davis D, Escamilla-Cejudo JA. His panic health in the USA: a scoping review of the literature. Public Health Rev. 2016;37:31.

19 United States Census Bureau. Hispanic heritage month 2020. 2020. Available from: https://www.census.gov/newsroom/facts-forfeatures/2020/hispanic-heritage-month.html.

20 Pérez-Escamilla R, Garcia J, Song D. Health care access among hispanic immigrants: ¿Alguien Está Escuchando? [is anybody listen?]. NAPA Bull. 2010;34(1):47-67.

21 Vadaparampil ST, Wideroff L, Breen N, Trapido E. The impact of acculturation on awareness of genetic testing for increased cancer risk among Hispanics in the year $2000 \mathrm{Na}$ tional Health Interview Survey. Cancer Epidemiol Biomarkers Prev. 2006;15(4):618-23.

22 Hamilton JG, Shuk E, Arniella G, González CJ, Gold GS, Gany F, et al. Genetic testing awareness and attitudes among Latinos: exploring shared perceptions and gender-based differences. Public Health Genomics. 2016;19(1):34-46.

23 Fisher ER, Pratt R, Esch R, Kocher M, Wilson $\mathrm{K}$, Lee $\mathrm{W}$, et al. The role of race and ethnicity in views toward and participation in genetic studies and precision medicine research in the United States: a systematic review of qualitative and quantitative studies. Mol Genet Genomic Med. 2020;8(2):e1099.

24 McGuinness JE, Trivedi MS, Silverman T, Marte A, Mata J, Kukafka R, et al. Uptake of genetic testing for germline BRCA $1 / 2$ pathogenic variants in a predominantly Hispanic population. Cancer Genet. 2019;235-6:72-6.

25 Lopez DS, Fernandez ME, Cano MA, Mendez C, Tsai CL, Wetter DW, et al. Association of acculturation, nativity, and years living in the United States with biobanking among individuals of Mexican descent. Cancer Epidemiol Biomarkers Prev. 2014;23(3):402-8.

26 Ceballos RM, Knerr S, Scott MA, Hohl SD, Malen RC, Vilchis $\mathrm{H}$, et al. Latino beliefs about biomedical research participation: a qualitative study on the US-Mexico border. J Empir Res Hum Res Ethics. 2014;9(4):10-21.

27 Hohl SD, Gonzalez C, Carosso E, Ibarra G, Thompson B. "I did it for us and I would do it again": perspectives of rural Latinos on providing biospecimens for research. Am J Public Health. 2014;104(5):911-6.

28 Butterfield RM, Evans JP, Rini C, Kuczynski KJ, Waltz M, Cadigan RJ, et al. Returning negative results to individuals in a genomic screening program: lessons learned. Genet Med. 2019;21(2):409-16.
29 Shaibi GQ, Kullo IJ, Singh DP, Sharp RR, De Filippis E, Cuellar I, et al. Developing a process for returning medically actionable genomic variants to Latino patients in a federally qualified health center. Public Health Genomics. 2018;21(1-2):77-84.

30 eMERGE Consortium. Harmonizing clinical sequencing and interpretation for the eMERGE III network. Am J Hum Genet. 2019;105(3):588-605.

31 Kalia SS, Adelman K, Bale SJ, Chung WK, Eng C, Evans JP, et al. Recommendations for reporting of secondary findings in clinical exome and genome sequencing, 2016 update (ACMG SF v2.0): a policy statement of the American College of Medical Genetics and Genomics. Genet Med. 2017;19(2):249-55.

32 Kullo IJ, Olson J, Fan X, Jose M, Safarova M, Radecki Breitkopf C, et al. The return of actionable variants empirical (RAVE) Study, a Mayo Clinic genomic medicine implementation study: design and initial results. Mayo Clin Proc. 2018;93(11):1600-10.

33 Shaibi GQ, Kullo IJ, Singh DP, Hernandez V, Sharp RR, Cuellar I, et al. Returning genomic results in a Federally Qualified Health Center: the intersection of precision medicine and social determinants of health. Genet Med. 2020; 22(9):1552-9.

34 Creswell JW, Creswell JD. Research design qualitative, quantitative, and mixed methods approaches. Sage Publications; 2019.

35 Culhane-Pera KA, Moua M, Vue P, Xiaaj K, Lo MX, Straka RJ. Leaves imitate trees: Minnesota Hmong concepts of heredity and applications to genomics research. J Community Genet. 2017;8(1):23-34.

36 Malen R, Knerr S, Delgado F, Fullerton SM, Thompson B. Rural Mexican-Americans' perceptions of family health history, genetics, and disease risk: implications for disparitiesfocused research dissemination. J Community Genet. 2016;7(1):91-6.

37 Vega WA, Rodriguez MA, Gruskin E. Health disparities in the Latino population. Epidemiol Rev. 2009;31(1):99-112.

38 Campos B, Schetter CD, Abdou CM, Hobel CJ, Glynn LM, Sandman CA. Familialism, social support, and stress: positive implications for pregnant Latinas. Cultur Divers Ethnic Minor Psychol. 2008;14(2):155-62.

39 Clayton EW, Ross LF. Implications of disclosing individual results of clinical research. JAMA. 2006;295(1):37-8.

40 Squires A. Methodological challenges in cross-language qualitative research: a research review. Int J Nurs Stud. 2009;46(2):277-87.

41 Temple B, Young A. Qualitative research and translation dilemmas. Qual Res. 2004;4(2): 161-78.

42 González Burchard E, Borrell LN, Choudhry S, Naqvi M, Tsai HJ, Rodriguez-Santana JR, et al. Latino populations: a unique opportunity for the study of race, genetics, and social environment in epidemiological research. Am J Public Health. 2005;95(12):2161-8.
Latino Participants Receiving Neutral Genomic Screening Results
Public Health Genomics 2021;24:44-53 DOI: $10.1159 / 000513219$ 